\title{
Political geographies of globalization
}

\section{Moisio, Sami}

Edward Elgar

2018-11-30

Moisio , S , Luukkonen , J \& Jonas , A E G 2018 , Political geographies of globalization . in Handbook On the Geographies of Globalization . , 9 , Edward Elgar , Cheltenham , pp.

135-147 . https://doi.org/10.4337/9781785363849.00018

http://hdl.handle.net/10138/311035

https://doi.org/10.4337/9781785363849.00018

acceptedVersion

Downloaded from Helda, University of Helsinki institutional repository.

This is an electronic reprint of the original article.

This reprint may differ from the original in pagination and typographic detail.

Please cite the original version. 
Moisio, S., Luukkonen, J. \& Jonas, Andrew E.G. (2018). Political geographies of globalization. In Kloosterman, R.C., Mamadouh, V. Terhorst, P. (eds.) Handbook on the Geographies of Globalisation. 135-147. Edward Elgar Publishing, Cheltenham.

\section{Political geographies of globalization}

Sami Moisio (Department of Geosciences and Geography, University of Helsinki)

Juho Luukkonen (Department of Geosciences and Geography, University of Helsinki)

Andrew E.G. Jonas (Geography, School of Environmental Sciences, University of Hull)

\section{Introduction}

During the past decades, the word globalization has become the mantra through which politicians, scholars, policy commentators, the media and even members of the public seek to understand and explain the ways the contemporary world works. This chapter seeks to elaborate upon a phenomenon which can be called political geographies of globalization (see also Kelly 1999; Sparke 2006). By this we refer to the different political discourses and related imaginaries, policy practices and regimes of governance through which globalization can be understood as being constantly produced in and through political geographical formations.

Rather than conceptualizing the global as a discrete scale or level of analysis we highlight specific policies and processes which are globalizing in nature. In particular, we comprehend globalization both as an actually existing process which links places - cities, regions, etc., institutions (especially the state) and people (notably workers) - and creates interdependencies between them, and as a politically loaded rhetorical device used to rationalize and legitimate myriad political decisions and 
policy practices. In doing so, we stress the need to examine the ways in which globalization can be understood as being constituted through the "national" and the "local", and how the state - or its absence at least in respect of policies that support workers rather than capital - has been crucial in enhancing the emergence of these as relational spaces of globalization.

Given the huge amount of literature on the political geographies of globalization, we present a decidedly partial mapping of the existing literature. In the ensuing sections, we single out three interlinked and partly overlapping issues through which the political geographies of globalization

can be mapped out: 1) the spatial formations of globalization and the state, 2) the "globalizing" role and "globalized" nature of public policy, and 3) the globalizing regimes and policies of labor. These are areas of interest which sometimes come together in the attempts of governments, international organizations, business associations, consultant companies and the like to govern and come to terms with the purportedly messy sphere of the global. Often, however, these function as separate spheres of political intervention and, as such, are represented as discrete spaces of state intervention in the academic literature on globalization. For example, work on labor geographies tends to examine national spaces of labor regulation quite separately from local spaces of labor control. Nonetheless, towards the end of our chapter we consider ways in which these processes increasingly converge within particular cities and regions, producing in new political geographies of globalization.

\section{Political geographical formations of globalization and the territorial state}

A great variety of spatial formations has been discussed under the rubric of globalization to depict the political economic changes that began to take shape in the $1990 \mathrm{~s}$ - in particular as a consequence of rapid development of information and communications technologies, pervasive financialization and the increasing mobility of at least some segments of capital along with ideas 
and commodities. It has been typical to argue that the economy is a driver of globalization to which the state is forced to merely "react". Rather than repeating this economic determinism we elaborate three themes which disclose how the territorial form of the state is being reimagined and represented in new ways, and how the state can be understood as a key driver of globalization.

Firstly, since the 1990s, spatial formations such as networks and what may be called exceptional economic spaces have been associated with political geographies of globalization. Globalization, in this context, is understood as being constituted by relational spaces that challenge the national territorial hierarchies that purportedly characterized the Fordist-Keynesian production of welfare statehood. Perhaps the most discussed theory of the networked nature of globalization was developed by Manuel Castells in 1990s. Accordingly, the digital revolution and concomitant information age and "new economy" is built on networks which link states, institutions and individuals in different tapestries. But rather than producing a flat world, differentiation between those who are and those who are not part of the networks of informational capitalism characterizes the contemporary condition.

What Castells (1996) calls network society consists of new network enterprises, states, places, regions, and subjects, and is both integrating and fragmenting. Even if the network society diffuses throughout the entire world, it does not include all people: it is rather characterized by a growing gap between winners and losers. In order to be located on the winners' side of the network society, states and cities are forced to tailor new kinds of spatial strategies and build a kind of spatial exceptions (Ong 2006) within their fabric.

The concept of spatial exception resonates with the argument by Saskia Sassen on the structuration of the global inside the national. The national can therefore be understood as a pivotal site for the 
global, and the global gets constituted inside the national through particular spatial exceptions. The state can for instance participate in the making of protected jurisdictions for firms operating globally (Sassen 2013, p. 37). The list of these spatial exceptions or transversal spaces - territories or jurisdictions within nation state territories - is extensive and would include territorial formations such as financial centers, special economic zones, innovation centers and offshore production zones which are often exempted from usual national regulations covering corporate taxation, labor standards, and suchlike. This argument is theoretically important as it implies that the national territory of the state can be effectively denationalized in the attempts of the state to tap into or enhance the processes of globalization. This may also lead to a particular empowering of some agencies of the state as they become more important given their operational importance in connecting the state to the processes of global economy (Sassen 2010) or global governance. Correspondingly, other agents - especially workers - are disempowered.

Secondly, the political geographies of globalization are being disclosed in literature on the rise of global cities, global city regions and city regionalism. Large urban agglomerations in the global North in particular are often understood as sites of globalization. These cities are understood through their functions and substances and the degree of integration into the purportedly "global" economy. What Richard Florida (2017) calls super-star cities are sites of investment or venture capital, foreign exchange, as well as sites of high order business services related to marketing, accounting and law, innovation activities developed by talented people, cultural industries and urban amenities. These cities are nests of headquarters of multinational and national corporations, leading international organizations, media organizations, and professional and trade organizations. This kind of spatial concentration of economic and governance activities, as well as the related regional clustering of other activities around these cities, has led to a powerful political geographical articulation of city-regions. Allen Scott (2001, p. 813, 817), for instance, writes about 
"an extended archipelago or mosaic of large city-regions" which "increasingly function as the spatial foundations of the new world system that has been taking shape since the end of the 1970s."

Mapping out these spatial formations disclose political geographies of capitalist globalization and the associated re-organization of the spaces of finance, production and governance. It has therefore been argued that the increasingly transnational form of capitalism and the associated technological developments have from the 1990s onwards generated a spatial structure of world economy that is characterized by rapidly growing economic and political role of city-regions that may also cross state borders (Jonas and Moisio 2016). The literature on global city-regions generally deals with major urban agglomerations as key spaces of capital accumulation and within which human capital and productivity increasingly concentrate (see e.g. Scott et al. (2001, pp. 11-2). The rise of such global city-regions is, however, fraught with all sorts of distributional and political tensions not just within them but also across the wider state territory in which they are situated (Jonas 2013).

It has become commonplace not only for urbanists, consultant companies, globalization boosters and businesses firms (which also construct and finance urban infrastructures) but also for nationstate policy makers and politicians to argue that the strategic role of cities and city-regions has grown fundamentally during the past two-three decades. In such a geopolitical imaginary, the growth of major cities and city regions is conceived of as an inevitable global phenomenon orchestrated by market forces, one which proceeds beyond politics, political regulation and the territorial state. Policy analyst Parag Khannah's (2016) Connectography is one among the many attempts to tell a story about the contemporary de-territorializing global processes and the related ways in which the future is being shaped less by states than by connectivities of urban hubs and flows. 
Particular notions of urbanization as an apolitical global trend has become one of the key constituents of the geopolitical discourses of globalization. We believe that these geopolitical discourses on the inevitability of large scale urbanization and "connectography" play a significant constitutive role of contemporary capitalist expansion which is fundamentally grounded upon circulation of capital through urban built environments, technologies and infrastructures, urban consumption and the related urban needs and desires.

Finally, rather than understanding that the state has been hollowed out by globalization, the political geographies of globalization point to the qualitative transformation of the state from the $1980 \mathrm{~s}$ onwards. Accordingly, the contemporary conjuncture is marked by back and forth movement of the processes of state de-territorialization and re-territorialization and the relativization of scale. In such a perspective, the state is not a static object but rather its contemporary geography and re-worked scalar organization both results from and is a constitutive elements of the capitalist process of restructuring (Brenner 2004). In other words, the national state has a crucial role as an agent, site and medium of global restructuring that is often labelled as globalization. Similarly, the seemingly relational, mobile and de-territorializing capitalist globalization inescapably hinges upon the production of relatively fixed and immobile socio-spatial configurations (Ibid., p. 33).

What has been said above reminds us that the state is a constantly changing social organization, a process rather than a thing. As Bob Jessop (2016, p. 10) suggests, the state and its constituent powers can be understood as made up of "an institutionally and discursively mediated condensation of a changing balance of forces that seek to influence the forms, purposes, and content of polity, politics and policy". The spatial re-working of the territorial state thus brings together different actors who operate with different socio-cultural resources. Since 1980s, this re-working has also increasingly involved what Leslie Sklair (2001) calls the transnational capitalist class which 
arguably operates through distinctively "global" or "post-national" priorities, interests and loyalties, and whose actions are often predicated upon a particular geopolitical imaginary of a flat, borderless and networked world. Indeed, the transnationalization of state apparatus has been associated with the experienced tensions in many state contexts between the drive to equalize capital investment across space on one hand, and the pressure to differentiate such investment in order to exploit placeand territory-specific conditions for accumulation, on the other (Brenner 2004).

\section{Globalizing and globalized public policies}

Political geographies of globalization are produced in public policy discourses and practices. Urban policy, for instance, is not simply a blueprint or outcome of political processes developed in response to globalization. Rather the policy should be understood as playing a constitutive role in the production of globalization. To put it concretely, competing of cities through marketing and branding strategies, for instance, is not just a response to globalization but it also constructs a space of globalization in the form of marketing and branding practices and strategies that circulate from one city to another across the globe (e.g. McCann 2011). From our perspective, the globalization of policies involves two significant dimensions, i.e. the globalization of policymaking processes and the globalization of the policy substances.

Firstly, the globalization of policymaking processes denotes the reassembling of governance structures as new actors and activities become involved in solving policy problems which spread across jurisdictional and administrative boundaries. In political geography terms, the shifts in the geographies of governance involve the emergence of new territorial and relational modes of governance and alliances of power as well as the rescaling of state powers and responsibilities "vertically" and "horizontally" to various trans- and supranational institutions, regional authorities 
and non-state actors. One manifestation of the new geographies of the internationalized governance structures is also the emergence of global policy networks, a sort of "boundary crossing web of influences that shape political and policy decisions" (Prince 2012, p. 189).

Global policy networks affect significantly policymaking practices by engaging local, situated policies to broader international contexts. Among the government actors such as supra-national, national and regional public authorities, global policy networks grasp together non-government actors such as policy consultants and advisors, lobbyists, academics and other experts to international policy communities which guide and shape policy practices in national or local political contexts (Prince 2012; Larner and Laurie 2010). Within these networks, policy ideas developed elsewhere pass and become localized in new situations and geographical contexts.

The global policy networks are part of the extension of the pre-existing spaces of governance to multiple "elsewheres" simultaneously as well as the emergence of entirely new ones. Spaces of governance refer to both to physical locations and social spaces which gather policymakers around particular policy issues. In these sites, policymakers produce, circulate and modify policy ideas and seek solutions to shared policy problems at stake (Bachmann 2015; Temenos and McCann 2013). While administrative territories still remain as central components in defining the composition and scope of these spaces, the emergence of global policy networks and involvement of new actors have extended these spaces beyond their territorial boundaries. However, this has not only meant the exposure of national or regional policies under the influence of international political organizations such as the EU, World Bank or OECD but also the opening of the possibilities for policymakers to engage and articulate policy practices and goals through wider political rationalities and more powerful political actors (cf. Cox 1998). 
Secondly, the globalization of policy substances does not refer only to the contingent transferring or copying of individual policy ideas between places but also relates to the emergence of shared transnational or global policy cultures (cf. Toly 2011). This involves the spreading and adoption of similar kind of policy goals, measures and discourses.

In critical political geographies, the globalization of policy substances is often associated with the emergence and entrenchment of neoliberalism as "a globally hegemonic regime of governance and as a system of governmentality" (Sparke 2006, 364) (e.g. Brenner and Theodore 2002; Peck and Theodore 2010; Prince 2012). Neoliberal governance has become globally spread and widely adopted "standardized policy framework" (Sparke 2006) advocating market-oriented policy strategies such as deregulation, pro-risk attitudes, incorporation of private sector actors, reduction of public expenses, increasing the efficiency of public sector, self-evaluation and business friendly decision making (cf. Sparke 2013).

A key tenet of the neoliberal policymaking is the rise of a sort of audit culture which refers to the internationalization and institutionalization of the principles and techniques of calculation, accountancy and financial management as an essential part of policy practices and governance processes (Shore and Wright 2015, 24). This governing by numbers has become a normalized part of the day-to-day-routines of public institutions and policy organizations across the world. European Union, for instance, have been eager to apply calculative practices of measurement and ranking for evaluating the policy performances around the EU territory (e.g. Luukkonen and Moisio 2016). These standardized evaluation methods have become popular because they are easily inserted to new places and they produce harmonized and simplified information of the often complex and messy context-specific situations (Prince 2016). 
The adoption of the audit culture in policy practices involves two kind of spatial implications. First, audit techniques contribute to the formation of "topological connections" between particular places and policies. In geographical policy mobility literature these connections refer to processes of presencing and proximity (Robinson 2013, p. 10) or virtual relations between places and policies distinct from the physical or material connections of the policy networks - emerging from the standardized and harmonized practices of measurement and comparison (Prince 2016). A concrete example of the topological relations are the global city-rankings which have become routine part of the international urban policies. These rankings bring seemingly distant and differing cities and the associated urban policies together into international league tables and make them amenable to comparisons in global level. The global city-rankings not only drive cities to compete with each other over standings in the league tables but also improve the capacity of the international consultancies, the European Commission, the OECD and other powerful centres of calculation which often compile the listings, to regulate and govern cities at distance (cf. Kitchin et al. 2015).

Second, different auditing techniques play a central role in the so-called "territory work" (Moisio and Luukkonen 2017), i.e. in the reformulation and emergence of territories as objects of policy and governance. The rising popularity of the audit culture illustrates how policies are understood as "political technologies" which remove political problems from the realm of politics and recast them in the neutral language of science (Dreyfus and Rabinow 1982, p. 196). However, although calculative practices of measurement and ranking are often deemed as value-free tools for policy management, several authors have pointed out how they are essentially connected with particular globally hegemonic political imaginaries such as "the knowledge-based economy" (e.g. Luukkonen and Moisio 2016) and "city-regionalism" (e.g. McCann 2008). These imaginaries form mental frameworks which delimit policymakers' perceptions of territories as policy objects. They guide policymakers to prefer particular modes of geographical knowledge and choose particular indicators 
and indices through which territories are examined and converted as manageable and auditable economic and/or political entities.

\section{Globalizing policies and regimes of labor}

Approaching globalization as a set of geographically-mediated political processes requires that due consideration is paid to how class relations and tensions in capitalism are mediated through a variety of state and non-state policies and spatial practices. From the political vantage-point of capital, some of these policies and practices are designed to suspend the conflict between capital and labor at the point of production. For example, place-based labor control practices - or local labor control regimes - often emerge within and around particular localities in order to enable capitalist firms to integrate labor into the local production system and forestall worker resistance (Jonas 1996). Such practices tend to be found in industrial localities and regions where workers' institutions and political identities have been profoundly shaped by social interactions that extend from the workplace into the living place. From the perspective of workers, however, it is dangerous to assume that the outcomes of local political struggles around globalization in such places best serve their objective class interests. Instead, local factions of capital and organized labor might enter into political alliances designed to promote further rounds of economic growth rather than to redistribute income and resources. In such situations, state interventions, such as tax concessions for multinational corporations or the negotiation of harsher labor laws, lend a territorial rather than class political inflection to struggles around the globalization of capitalist production and economic development (Cox and Mair 1988).

Following Gramsci, the rise to dominance of a particular regime of production (e.g., the Fordist system of mass production in the early twentieth century) is generally associated with a sustained period of cultural hegemony in which the ruling class adopts a range of cultural and political practices in order to 
control the workforce and accumulate capital (Gramsci 1971). Neo-Gramscian regulationist approaches to the state (see, e.g., Jessop, 2016) refer to such periods as regimes of accumulation, which in turn are supported and sustained by corresponding modes of societal regulation, the broad aims of which are to regulate and distribute the social product between capital and labor, respectively (see, e.g., Aglietta 1979/2005). However, the emergence of a particular mode of social regulation and the degree to which it coalesces at the national scale are contingent political outcomes reflecting national as well as regional and local differences in the composition of class interests and political forces in civil society. Here the concept of political geographies of globalization is useful for investigating the social, economic and political conditions under which spatio-regulatory fixes are achieved not just nationally but also locally within different national territories (Peck and Tickell 1994).

At a general level, under Fordism the national state played a strategic role in setting the regulatory context for collective bargaining agreements between organized labor and capital. National spatial regulation in turn underpinned a geopolitical context in which multinational firms could make decisions about how to allocate production between different places, regions and countries on the basis of certain expectations about productivity, wages and potential profits. This led to the development of a finely-tuned international division of labor centered around the major industrial regions of North America, Europe, and parts of Asia. Nonetheless, factory owners and managers operating in particular regions and localities continued to experiment with local labor control regimes depending on how local labor requirements and skills could be coordinated with national production objectives (Jonas 1996). In some cases, the state intervened to enhance the local supply of labor by, for example, encouraging the development of new towns in peripheral regions (Cox 2016). Similarly, local political jurisdictions used variations in productivity, skills and labor costs as basis for competing for jobs and a specific place in the wider territorial division of labor. 
Following the closure of Fordist branch-plant industries in the 1970s and 1980s, subsidies by regional governments and, in Europe, the European Union (EU) compensated, at least in part, for shortfalls in income and national public investment. The net general effect was eventually to establish a worldwide production system which was nonetheless based on highly organized national political economies. At the same time, there remained in place finely-grained local and regional political differences resulting from the effects of different spatial structures of production on local class, gender and race relations (Massey 1984, 1995).

As uneven development intensified even further, places continued to jostle for a position within wider divisions of production, contributing to a politics of urban and regional development often accentuated by national differences in state structures and institutions. At the national level, for example, the contemporary political landscape of globalization is increasingly fought around immigration laws, producing a variegated landscape of political struggle around national labor regulation. ${ }^{1}$ At the local level, it is marked by rapidly diverging "high road' and "low road" local accumulation strategies (Gough 2012).

\footnotetext{
${ }^{1}$ One can compare and contrast, for instance, recent national political debates about labor and immigration in member EU countries. Following national elections in the Netherlands in 2017, attempts to form a cross-party national coalition government foundered due to inter-party disagreements over the country's immigration laws. In the United Kingdom, in the wake of "Brexit" (the 2016 referendum vote to leave the EU) the Conservative government has built its winning electoral strategy around proposals to re-introduce stricter national controls on the influx of lowskilled labor from the EU. In the meantime, the second largest UK political party, Labour, has focused its strategy on addressing wage disparities and working conditions.
} 
Those who recognize capital's ongoing ability to innovate, experiment and compete tend to refer to selective cases of "high road" local political responses where new labor organizations have emerged to extract limited concessions from capital. Whilst making the case that the United States (US) is an example of national political exceptionalism, $\operatorname{Cox}(2016$, p. 226) nonetheless points to the recent rise of new initiatives within the organized labor movement, which by-and-large have been focused around major urban centers:

These are the initiatives of the various urban-centered organizations around the country that emerged in the 1990s, funded by labor and foundations, with an agenda focused on labor and development issues. Some of them contained "new economy" in their titles as in the Los Angeles Alliance for a New Economy (LAANE) and the Connecticut Center for a New Economy (CCNE), and very loosely one might say that, to a degree, they were responding to problems thrown up by a period of rapid economic transformation: in particular the emergence of a bipolar income distribution, a related growth of low-paying service jobs, the erosion of the minimum wage and a continued decline of union membership.

However, local initiatives to challenge growing wage disparities, such as campaigns for a living wage, are becoming far more widespread and, in terms of their organizational geography, have much more in common with each other than is implied by Cox. Indeed, Peck (2001) points to a more dominant "low road" tendency in respect of labor regulation, namely, the gradual dismantling of national scale forms of welfare provision and their replacement by local-scale arrangements structured around principles of workfare and contingent labor. The accelerated emergence of such experimental city-based "workfare states" in the first two decades of the twentieth century is symptomatic of the rise of an arguably more 
insidious and decidedly global form of cultural hegemony based around the free market, competition and a relaxation of national labor regulation, a.k.a. neoliberalism.

Nevertheless, the difference that geography makes to the globalization of labor regulation continues to matter. For example, the pressure on workers, communities and civic organizations in different places to experiment and innovate rather than resist in order to survive and compete appears to lend credence to claims by politicians, consultants and academics that contemporary forms of globalization are being reconstructed around exceptional spaces (Ong 2006) - i.e., particular territories, such as new industrial spaces, global city-regions, etc., within which the knowledge economy and the creative class tend to converge. However, it is less clear how the liberal economic policy rhetoric associated with the rise of this new urban economy can be reconciled with the emergence of local labor control regimes within major cities (especially former global industrial centers) around which the relationship between capital and labor is being (re)constructed in quite new and subtle, yet no less exploitative, ways (Hastings and Mackinnon 2017). And if labor agency has not completely disappeared, and all sorts of new social movements are indeed coalescing around issues that affect labor's reproduction, it seems that class tensions have far from disappeared from the political landscape of globalization; instead, such tensions are best revealed in the new territorial political formations which are to be found in new economic spaces and city-regions.

So if recent years have arguably witnessed the unraveling of so-called "organized capitalism," the fraught balance of power between capital and labor continues to produce divergent political geographies of globalization. For example, the globalization of production is accentuating differences between the Global North and Global South in how labor is socially integrated into the production process. In countries, such as the Philippines, which are heavily dependent upon foreign direct investment by US multinational firms, the development of local labor control regimes depends upon 
the activities of a variety of non-state political actors ranging from national labor organizations and private recruitment agencies to local village and community leaders (Kelly 2001). In the US, by way of comparison, capital continues to recruit internationally for cheap labor, and immigrant workers have developed their own transnational support networks in order to compensate for the absence of social support from the US state. Miraftab (2016) documents how migrant meatpacking workers in the US Midwest today draw upon social relations and resources in their communities of origin - in Mexico and western Africa - in order to facilitate their integration into the local production system. If the new economic geographies of capitalism depend upon the construction of new labor control regimes, these in turn are premised upon a relational politics of social reproduction which increasingly connects places in the Global North to those in the Global South.

Finally, in the post-Fordist regulatory vacuum created by state withdrawal from social welfare provision one might have expected capital to step in and develop strategies to compensate, at least in part, for the social predicament of workers. There is an assumption in much of the literature on the new urban economy that, in lieu of the state, capital develops its own systems of collection action in order to address various negative externalities arising from spatial agglomeration and rapid urban growth (Storper 2013). Whilst this might arguably be the case for employers operating in certain successful or high-profile global city-regions, such as the Silicon Valley, there is also evidence from other places of a lack of corresponding levels of city-regional collaboration and emerging territorial-distributional struggles around issues of labor regulation. An example was recently reported in the Chicago Sun Times (see Garcia 2017) in which suburban jurisdictions in the Chicago metropolitan area have resisted efforts by Cook County officials to introduce a minimum wage to match that of the City of Chicago, which plans to raise its minimum wage from US\$11 per hour in the summer of 2017 to US\$13 per hour by 2019. Local businesses in some Chicago suburbs have lobbied local politicians to use local powers of "home rule" to opt out of a county-wide ordinance designed to raise the minimum wage. 
This brief vignette suggests that new regimes of labor regulation and control continue to be shaped by nationally- and locally-specific political geographies of globalization.

\section{Concluding remarks}

In this chapter, we have sought to highlight a set of overlapping objects, subjects and processes that have to do with political geographies of globalization. We have firstly argued that the contemporary condition may be understood as being structured partly around "hub and flow imaginaries" and related "exceptional" spatial formations that are its constituents. In our reading, the contemporary processes associated with hubs and flows and the set of other "relational spaces" do not signal deterritorial geoeconomic condition in which the territorial state is hollowed out. Rather, these imaginaries reveal back and forth nature of the contemporary state territoriality. At the present conjuncture, the state constantly seeks to re-territorialize, nationalize and "fix in place" the relational spaces of contemporary capitalism. But at the same time governments seek to deterritorialize and internationalize the state through increasingly spatially selective strategies in order to be connected to all sorts of "global networks" of money, talent, innovations and ideas. Much empirical work is still needed in order to disclose the ways in which states are spatially transformed within such a process (Moisio 2017).

Secondly, we have highlighted that the globalization of policies is a process which not only connects policy actors and regimes across space and time but also contributes to the emergence of new spaces of governance and to the formation of new governable spaces. Thus, while in the geographical literature on globalization focus has usually been in either the globalization of policy processes or policy substances, they ought to be understood as inseparable dimensions which both 
need to be taken into account when scrutinizing the effects of globalization on the daily practices of policymakers.

Thirdly, we argue that globalization can be examined as a set of geographically-mediated political processes involving various state and non-state policies and spatial practices designed to manage class relations and tensions in capitalism. Here we can identify both globalizing and localizing political tendencies at work in respect of the social control and regulation of labor. On the one hand the extension of capitalist production on a global scale and the corresponding shrinkage of the welfare functions of the national state has forced workers to develop international networks to support their social reproduction as a class. On the other hand, capitalist firms increasingly rely upon local experimentation in order to adjust to the changing social requirements of production. At the same time, widening of wage disparities within the workforce has engendered a variety of local and regional political initiatives on behalf of labor, which nonetheless continue to be resisted by employers and their political allies. Despite the much-vaunted benefits of collaboration and collective action that inform contemporary discussions of globalization and the new urban economy, social divisions and conflict remain the order of the day in many places.

Finally, globalization can take different progressive and regressive forms, and it can be qualitatively directed to different dimensions of social life, as suggested by our efforts to focus on the state, public policy and labor, respectively, rather than transnational capital, which often is assumed to be the prime driver and beneficiary of globalization. Political geographies of globalization are therefore historically contingent, bound to various and often competing social forces, and inescapably open to contestation.

\section{References}


Aglietta, Michel (1979 [Reprinted 2005, trans. David Fernbach]), A Theory of Capitalist

Regulation: The US Experience. London: Verso.

Bachmann, V. (2015), 'Global Europa, ESPON and the EU's regulated spaces of interaction', Journal of European Integration, 37, 685-703.

Brenner, Neil (2004), New State Spaces, Oxford: Oxford University Press.

Brenner, N. and Theodore, N. (2002), 'Cities and the geographies of "actually existing neoliberalism", Antipode, 34, 349-379.

Castells, Manuel (1996), The Rise of the Network Society, Oxford: Blackwell.

Cox, Kevin R. (1998), 'Spaces of dependence, spaces of engagement and the politics of scale, or: looking for local politics', Political Geography, 17, 1-23.

Cox, K.R. (2016), The Politics of Urban and Regional Development and the American Exception, Syracuse, NY: Syracuse University Press.

Cox, K.R. and Mair, A. (1988), 'Locality and community in the politics of local economic development', Annals of the Association of American Geographers, 78, 307-25.

Dreyfus, Hubert L. and Rabinow, Paul (1982), Michel Foucault: Beyond Structuralism and Hermeneutics, Chicago: University of Chicago Press. 
Florida, R. (2017b), 'Why America's richest cities keep getting richer?', The Atlantic Cities, 12.4.2017. Last accessed at: https://www.theatlantic.com/business/archive/2017/04/richard-floridawinner-take-all-new-urban-crisis/522630/

Garcia, M. (2017), 'Cook County hiked the minimum wage, but maybe not really for you', Chicago Sun Times, Opinion, 17 March. Last accessed at: http://chicago.suntimes.com/opinion/cook-countyhiked-the-minimum-wage-but-maybe-not-really-for-you/amp/

Gough, Jamie (2012), 'Capital accumulation in space, capital-labour relations, and political strategy. In Andrew E.G. Jonas and Andrew Wood (eds), Territory, the State and Urban Politics. Farnham: Ashgate, pp. 89-112.

Gramsci, Antonio (1971), Selections from the Prison Notebooks, London: Lawrence and Wishart.

Hastings, Thomas and Mackinnon, Danny (2017), 'Re-embedding agency at the workplace scale: Workers and labour control in Glasgow call centres', Environment and Planning A, 49(1), 104-120

Jessop, Bob (2016), The State: Past, Present, Future. Cambridge: Polity.

Jonas, Andrew E.G. (1996), 'Local labour control regimes: uneven development and the social regulation of production', Regional Studies, 30, 323-338.

Jonas, A.E.G. (2013), 'City regionalism as a “contingent geopolitics of capitalism”,, Geopolitics, 18, 284-298. 
Jonas, A.E.G. and Moisio, S. (2016), 'City regionalism as geopolitical processes: A new framework for analysis', Progress in Human Geography, DOI:10.1177/0309132516679897 Available at: http://journals.sagepub.com/doi/pdf/10.1177/0309132516679897

Kelly, Phillip F. (1999), ‘The geographies and politics of globalization', Progress in Human Geography, 23, 379-400.

Kelly, P.F. (2001), 'The political economy of labor control in the Philippines', Economic Geography, 77, 1-22.

Kitchin, R., Lauriault, T. P. and McArdle, G. (2015), 'Knowing and governing cities through urban indicators, city benchmarking and real-time dashboards', Regional Studies, Regional Science, 2, 628.

Larner, W. and Laurie, N. (2010), 'Travelling technocrats, embodied knowledges: Globalising privatisation in telecoms and water', Geoforum, 41, 218-226.

Luukkonen, J. and Moisio, S. (2016), 'On the socio-technical practices of the European Union territory', Environment and Planning A, 48, 1452-1472.

Massey, Doreen (1984), Spatial Divisions of Labor: Social Structures and the Geography of Production, New York: Methuen. 
Massey, D. (1994), Space, Place and Gender. Cambridge: Polity Press.

McCann, E. (2008), 'Expertise, truth, and urban policy mobilities: Global circuits of knowledge in the development of Vancouver, Canada's 'four pillar' drug strategy', Environment and Planning A, 40, 885-904.

McCann, E. (2011), 'Urban policy mobilities and global circuits of knowledge: Toward a research agenda', Annals of the Association of American Geographers, 101, 107-130.

Miraftab, F. (2016), Global Heartland: Displaced Labor, Transnational Lives, and Local Placemaking, Bloomington: Indiana University Press.

Moisio, S. (2017), ‘Towards geopolitical analysis of geoeconomic processes', Geopolitics

Moisio, Sami and Luukkonen, Juho (2017), 'Notes on spatial transformation in post-Cold War Europe and the territory work of the European Union', In Peeter Vihalemm, Anu Masso, Signe Opermann (eds), The Routledge International Handbook of European Social Transformation. London: Routledge.

Olsen, J.P. (2002), 'The many faces of Europeanization', Journal of Common Market Studies, 40, $921-952$.

Ong, Aihwa (2006), Neoliberalism as exception. Mutations in citizenship and sovereignty, Durham: Duke University Press. 
Peck, Jamie (2001), Workfare States, New York: Guilford Press.

Peck, J. and Theodore, N. (2010), 'Mobilizing policy: Models, methods, and mutations', Geoforum, 41, 169-174.

Peck, Jamie and Tickell, Adam (1994), 'Searching for a new institutional fix: the after-Fordist crisis and global-local disorder', In Ash Amin (ed), Post-Fordism: A Reader. Oxford: Blackwell, pp. $280-316$.

Prince, R. (2012), 'Policy transfer, consultants and the geographies of governance', Progress in Human Geography, 36, 188-203.

Prince, R. (2016), 'The spaces in between: Mobile policy and the topographies and topologies of the technocracy', Environment and Planning D: Society and Space, 34, 420-437.

Robinson, Jennifer (2013), "'Arriving at" the urban/urban policy: Traces of elsewhere in making city futures. In Ola Söderström, Didier Ruedin, Shalini Randeria, Gianni D’Amato and Francesco Panese (eds), Critical Mobilities. London: Routledge, pp. 1-28.

Sassen, S. (2010), 'The global inside the national. A research agenda for sociology', Sociopedia.isa. Last accessed at: http://www.saskiasassen.com/pdfs/publications/the-global-inside-the-national.pdf Sassen, S. (2013), 'When territory deborders territoriality’, Territory, Politics, Governance, 1, 2145. 
Scott, A. (2001), 'Globalization and the rise of city-regions', European Planning Studies, 9, 813826.

Scott, Allen J., Agnew, John A., Soja, Edward and Storper, Michael (2001), 'Global city-regions', In Allen J. Scott (ed), Global City-Regions: Trends, Theory, Policy. Oxford: Oxford University Press, pp. 11-32.

Shore, C. and Wright, S. (2015), 'Governing by numbers: audit culture, rankings and the new world order', Social Anthropology/Anthropologie Sociale, 23, 122-128.

Sklair, Leslie (2001), The Transnational Capitalist Class, Oxford: Blackwell.

Sparke, M. (2006), 'Political geography: political geographies of globalization (2) - governance', Progress in Human Geography, 30, 357-372.

Sparke, Matthew (2013), Introducing Globalization: Ties, Tensions, and Uneven Integration, Chichester: Blackwell Publishing.

Storper, Michael (2013), Keys to the City, Princeton, NJ: Princeton University Press.

Temenos, C. and McCann, E. (2013), 'Geographies of policy mobilities', Geography Compass, 7, $344-357$. 
Toly, Noah (2011), 'Cities, the environment and global governance: A political ecological perspective', In Mark Amen, Noah Toly, Patricia McCarney and Klaus Segbers (eds), Cities and Global Governance: New Sites for International Relations. London: Ashgate, pp. 137-150. 